\title{
2 Fiscal reforms and institutional changes in the Andean region
}

\author{
Revenues volatility and unequal \\ distribution of regional income
}

\author{
Juan Pablo Jiménez $z^{1}$
}

\section{Introduction}

During the latest commodity boom (2003-2008), the fiscal authorities of the Andean countries introduced a series of reforms. These followed two objectives: to raise revenues by capturing the extraordinary rents of the sector that had increased significantly in that period due to the high prices of regional commodities on the world markets; and to distribute these revenues among the different levels of government, financing the recent decentralization initiatives in the region (Brosio \& Jiménez, 2012; Gómez Sabaíni et al., 2018). For the former, governments implemented different measures: new taxes were introduced, royalty schemes were strengthened, and taxes on extraordinary revenues were established. To distribute the revenues originating from the extractive industries, governments introduced schemes allowing most of the tax revenues to flow back into the producing regions, and also facilitating the process of decentralization of public expenditure responsibilities in these countries implemented in those years (Brosio \& Jiménez, 2012).

Starting in 2012, global prices for mineral and hydrocarbon products dropped dramatically. This new scenario not only meant a decline in the fiscal relevance of these revenues, but also reoriented government's objectives and led to a reprioritization of more sustainable investment and production levels in the sector. The fall of the fiscal revenues also had an important impact on budgets of subnational governments, reducing the capacity of the public sector to intervene in the economy.

The specialization on nonrenewable natural resources is the origin of the high territorial inequality of income in the region, both among and within countries. In the Andean region, the ratio between the regions with the highest and lowest per capita GDP generally exceeds 6:1, while in developed countries it is rarely more than 3:1 (Brosio et al., 2018; CEPAL, 2017; Muñoz et al., 2016). This structural high regional inequality of income is produced by several factors, but mostly by the geographic concentration of the production of nonrenewable natural resources.

The significantly unequal regional distribution of income translates into sharp fiscal disparities. This is the case for a tax base that is highly regionally 
concentrated such as the taxation on consumption (ingresos brutos in Argentina, selective taxes in Colombia); but is still more significant when the tax base is nonrenewable natural resources because their deposits are regionally very concentrated (Brosio et al., 2018; Muñoz et al., 2016).

In consequence, when fiscal resources are not allocated and distributed adequately, they tend to exacerbate the structural high regional inequality and other imbalances among jurisdictions in the same country. This emphasizes the importance of tax power and spending responsibility assignments, jointly with the design of equalization systems of the distribution of fiscal revenues from nonrenewable natural resources among the different levels of government (Brosio \& Jiménez, 2015).

In a context of the increasing decentralization of responsibilities from the central to subnational governments (Brosio \& Jiménez, 2012), the volatility of these fiscal revenues has also a significant impact on the fiscal capacities and causes territorial disparities.

The goal of this article is to review the fiscal reforms on the extractive sector carried out during the last boom phase and their impact on the public accounts, fiscal space, and regional inequality. It focuses on several countries of the Andean region (Argentina, Bolivia, Chile, Colombia, Ecuador, and Peru) for the period 1990-2016.

The chapter discusses the reforms on the taxation of natural resources and mechanisms for the allocation and distribution of these revenues as cases of institutional change in the Andean countries accomplished in recent years. It assesses their potential and limitations to improve some of the chronic curses of the region's fiscal policy: the inability to promote sustainable economic growth; the weakness to address the very unequal distribution of income, both personal and regional; the difficulties in implementing sustainable reforms that strengthen the public sector by increasing fiscal revenues and improving its distribution.

This article proceeds as follows: First, it describes the fiscal reforms and the instruments these use related to the exploitation of nonrenewable natural resources, for the appropriation, allocation, and distribution of tax revenues obtained. Second, it assesses the performance of these reforms in terms of their impact in tax revenues and fiscal accounts, at the level of the central governments and the subnational governments. At the subnational level, the institutions and their dynamics will be analyzed, with a focus on their relationship with the different tax capacities of the territories and the concentration of tax revenues from the exploitation of nonrenewable natural resources. In the final section, the chapter analyzes the characteristics resulting from the combination of productive specialization, legal framework and price cycle, the main challenges in the post-bonanza context, and some possible alternatives to confront them. It argues that in order to confront the challenges arising from the price decline of the post-boom period, the reforms need to pursue different objectives than those implemented in the boom period. They must both attend to 
the sustainability of the sector, in terms of production and investment, as well as compensate for the decrease in tax revenues, at different levels of government, and its territorial impact.

\section{Evolution of fiscal instruments, revenue collection, allocation, and distribution of nonrenewable natural resources}

\section{Revenue collection instruments and recent fiscal reforms in the region}

In the period under analysis, tax revenues from the exploitation of nonrenewable natural resources were an important source of public resources in the Andean countries, both for central and subnational governments, although they have recorded strong fluctuations.

Given the magnitude and persistence of the upward trend in the price cycle that began in 2003 and increased significantly the rents of the extractive sector, the producing and exporting countries in the region found sufficient space to introduce substantial reforms in tax regimes applied to the production of hydrocarbons and minerals. These reforms were adopted in all countries regardless of the political orientation of the government (Hanni et al., 2018).

\section{During the commodity boom}

In Latin American countries, the most direct way of appropriation of commodity rents and their subsequent transformation in fiscal resources has been, historically, by participation in exploitation, whether through state-owned enterprises or shareholding (Hanni et al., 2018). These companies are often subject to a special tax regime, which may consist of rent payments or fees, additional taxes for public companies, or indirect selective (excise) taxes on oil production.

During the commodity boom, the reforms accentuated the specialization of tax systems, especially in hydrocarbons and minerals in the region's producing countries. They increased state control over available resources, introduced new taxes, strengthened royalty schemes, and established taxes on extraordinary revenues. ${ }^{2}$

Between 2005 and 2012, the most important legal reforms to ensure public control of nonrenewable natural resources focused on the hydrocarbon sector (CEPAL, 2013). These measures among the selected countries included the nationalization of the sector through joint ventures in Venezuela (between 2005 and 2007); in Bolivia, the renegotiation of hydrocarbon contracts, the renationalization of the Huanuni tin mine (2006), and the nationalization of the Colquiri mine in Oruro (2012); the renegotiation of oil contracts in Ecuador (2010), where production-sharing contracts were changed to service contracts in which the state is the owner of all the crude oil extracted with the stipulation that the government would absorb $100 \%$ of possible increases in oil prices. 
Additionally, other governments strengthened state ownership mechanisms such as royalties, usually based on production, and specific taxes. This was especially important in the mining sector, where revenue generation through state participation in enterprises was relatively low in the past. Royalties and taxes have ensured a minimum payment for resources to national and subnational governments as a growing number of countries with a variety of political orientations introduced reforms in the systems of royalties. These include Bolivia (2005), Ecuador (2010), Colombia (2011), and Peru (2011). In addition, in Ecuador, the hydrocarbon law reform established the margin of sovereignty designed to guarantee the state minimum revenues of $25 \%$ of the gross production value in case of possible price decreases. ${ }^{3}$

Traditional income taxes with multiple tax rates and other special charges have been applied, often with progressive rates on public or private companies exploiting nonrenewable resources. This has been reinforced with the introduction of new collection instruments (as in the case of Bolivia and Chile) during the period between 2005 and 2012. For instance, in 2005 Bolivia introduced the direct tax on hydrocarbons (Impuesto Directo a los Hidrocarburos, IDH) which, in addition to royalties and shares of the treasury led to a $50 \%$ direct participation of the state in extractive revenues. Meanwhile, in 2006 Chile introduced the specific tax on mining activity, which was applied to a type of net income that included the financial costs of depreciation of capital goods and interest. This aimed at strengthening taxation on mining (complementing the corporate tax and the tax over remittances of profits abroad) while procuring not to discourage private investment. In Venezuela, tax rates on income from oil (50\%) were increased in 2006, and three new taxes were created: the oil extraction tax, the export registration tax, and the Special Contribution on Extraordinary Prices and Exorbitant Prices in the International Hydrocarbons Market. In 2011, Peru updated its mining laws and introduced profit-based rather than revenue-based royalties, introducing three profit-based taxes: a mining royalty (Law 29788), a special mining tax (Law 29790), and a special mining contribution (Law 29789), the latter being paid in addition to the mining royalty. This was designed with the objective to collect more taxes from the most profitable operations and to minimize the risks to the government's revenue stream through the commodity supercycle.

Moreover, given the high volatility of international prices of nonrenewable resources, several countries like Bolivia, Colombia, Ecuador, and Venezuela have also considered the implementation of taxes, duties, participations, or contributions linked to prices or extraordinary profits (windfall taxes). Although there is a wide heterogeneity in this area, all countries that introduced these types of fiscal instruments did it during the period of the price boom (20032008), clearly as a reaction to the enormous increase in profits associated with hydrocarbon and mineral sectors among the countries of the region.

As noted by Acquatella et al. (2013), in Latin America the advances in tax progressivity have been clearer and concrete in the oil sector than in the mining sector. For example, in the oil sector, production service contracts and risk 
service contracts are very common. They anticipate an increasing scale of state participation in the profits as the project reaches increasing rates of return. In contrast, the incorporation of such a concept in the tax treatment of the mining sector in the countries of the region remains in its infancy, since mining countries, as shown in Table 2.2, rely heavily on royalties and corporate income tax for revenue generation. Chile is to some extent the only exception.

\section{After the boom}

Since 2013, the prices of mining and hydrocarbon products have decreased strongly, as a result of a slowdown in growth and investment in China and structural changes in the supply of these products (such as the rise in hydrocarbon production driven by the application of fracking technology in the United States, see Hanni et al., 2018). This decrease has an important fiscal impact: it reduces fiscal revenues (Gómez Sabaíni et al., 2018).

The sharp drop in prices of these products in recent years meant not only a fall in the fiscal relevance of these revenues but also a reformulation of the objectives to be followed and the tools to be used. In this new context, governments started to prioritize not only the level of tax revenues but also their impact on the sustainability of investments and production in the sector (Hanni et al., 2018). In the post-boom, the reforms in the sector show a growing concern for stimulating investment and production and for private sector participation, in addition to the need to maintain the tax contribution of nonrenewable natural resources. Indeed, several countries in the region have enacted policy measures in recent years aimed at stimulating activity in the extractive sector while creating sectoral long-term investment and savings funds.

The latest changes in the extractive sector prioritize objectives such as the promotion of production and investment and the degree of flexibility through structural reforms. They aim at ensuring the participation of the private sector and the creation of programs and incentive schemes for production (for instance in Argentina and Bolivia).

In 2015, Bolivia approved the law for investment promotion in exploration and exploitation to promote investment in the sector. The production incentives included in the law are financed mainly through a new fund created by the same law, the promotion fund for investment in exploration and exploitation in hydrocarbons (Fondo de Promoción a la Inversión en Exploración $y$ Explotación Hidrocarburifera, FPIEEH), fed with $12 \%$ of the direct tax levy on hydrocarbons.

In the mining sector, the objectives of the reforms during this period reflect the concern to promote mining activity, especially in order to ensure a continuous flow of investment into the sector. In Ecuador, for example, a package of measures to promote the development of the mining sector was promulgated in 2013, which reformulated the application of the extraordinary income tax. The new tax will only apply once the concessionaire has recovered its investments. 


\section{Juan Pablo Jiménez}

\section{Volatility of the tax collection coming from the nonrenewable}

natural resources

The institutional reforms and innovations in the fiscal and tax framework previously analyzed, in addition to the evolution of international prices, meant a strong increase in tax revenues in the period 2003-2008, a subsequent deceleration, and a significant fall in recent years (2012-2016, see Figure 2.1b).

The inherent volatility of these revenues complicates fiscal policy management in nonrenewable natural resource-producing countries. This is especially true in countries where these revenues have had a high share of total revenue during the price-cycle boom period. As illustrated in Figure 2.2, the revenues from hydrocarbons and mining accounted for 30\% or more of the total public revenues during 2010-2011 in Bolivia and Ecuador, and more than 40\% in the Bolivarian Republic of Venezuela.

\section{Assignment and distribution of tax revenues from the exploitation of nonrenewable natural resources}

The increase in tax revenues from the exploitation of nonrenewable natural resources was an important source of public revenues, not only for the central governments, as noted in the previous section, but also for the subnational

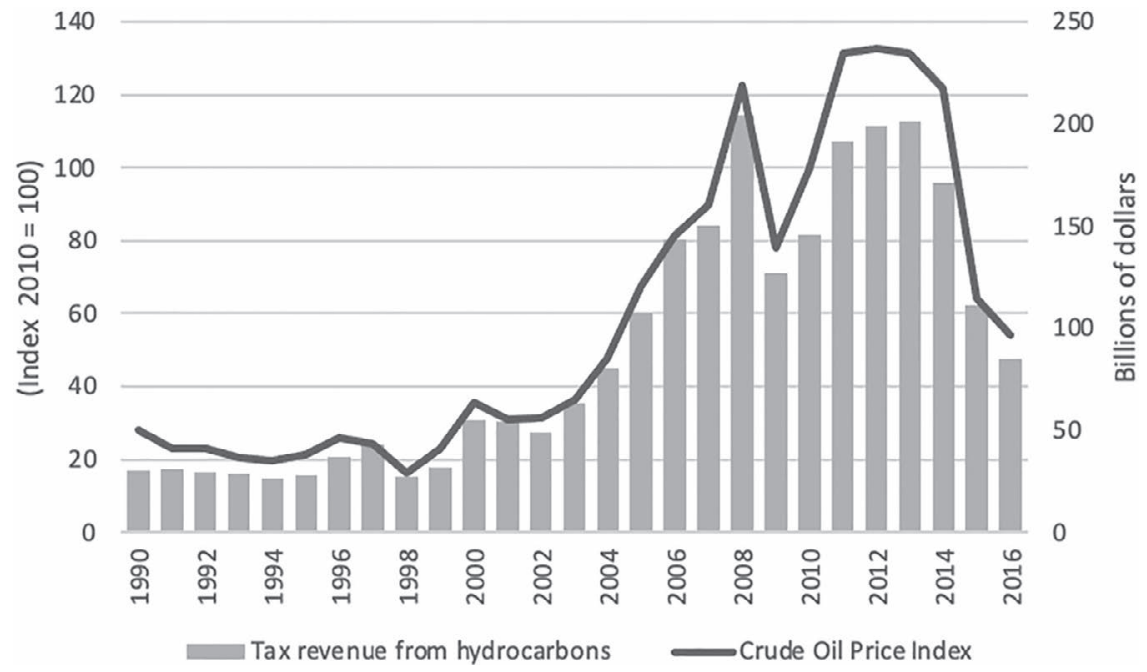

Figure 2.1a Latin America and the Caribbean: tax revenues from nonrenewable natural resources, by product, and related international price indicators, 1990-2016 $($ Index $100=2010)$ A. Hydrocarbons

Source: Hanni et al., 2018 


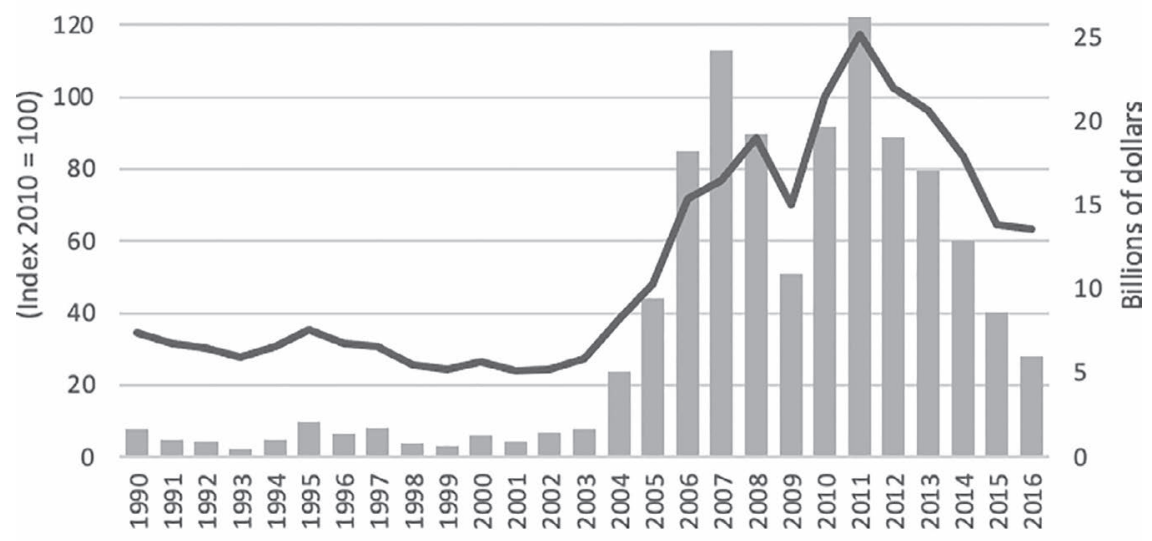

Tax revenue from mining Minerals and Metals Price Index

Figure 2.1b Latin America and the Caribbean: tax revenues from nonrenewable natural resources, by product, and related international price indicators, 1990-2016 (Index $100=2010)$ B. Mining Products

Source: Hanni et al., 2018

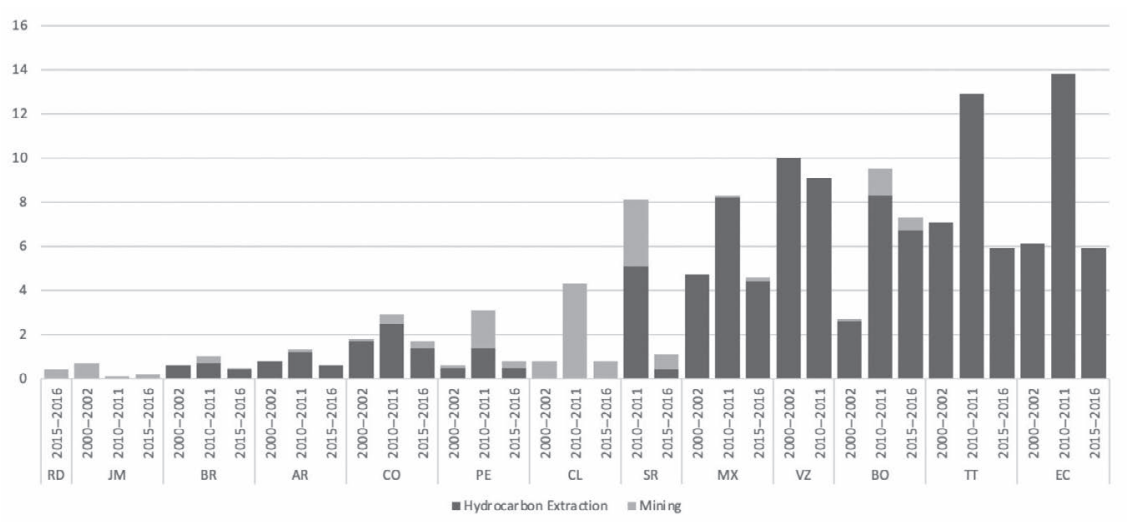

Figure 2.2 Latin America and the Caribbean (selected countries): participation of tax revenues from nonrenewable natural resources in total public revenues, 2000-2016 (Percentages)

Source: Hanni et al. (2018) 
ones (Brosio \& Jiménez, 2012). The use of this peculiar taxable base meant an improvement in the fiscal position of several subnational governments, especially in the regions where these products are produced.

Latin American countries in general, and the Andean region in particular, show a variety of different institutions for sharing rents from natural resources due to the different intergovernmental arrangements, ranging from classical federations, such as Argentina, to typical unitary states, such as Chile.

Contrary to old constitutions which remained silent on this issue, recent constitutions frequently, though not always directly, address it, because the sharing of rents from natural resources has become an inevitable component of the constitutional pact. Only in Argentina does the constitution assign ownership explicitly to the provinces. In all the other countries, ownership is assigned to the central government or is left unsettled by assigning ownership to the people (Bolivia), or to the nation (Peru). However, congruent with the international practice, rent sharing is not determined by the assignment of ownership, but rather by the sharing of tax bases, as in Argentina, and by the sharing of tax revenue.

With only two exceptions, Chile and Venezuela, all countries recognize the sharing of rent in favor of subnational governments. It is worthwhile noting that despite the fact that the first has always been a unitary and centralized country and the second has always been a federation, rent centralization prevailed in both countries.

The Andean countries represent an interesting example regarding the sharing issue. Bolivia, Colombia, Ecuador, and Peru are all unitary states that have embarked since the 1990s on a decentralization process leading to the creation of regional systems. The same countries allocate a substantial share of their revenues from natural resources to their subnational governments. These countries provide evidence to the argument that the combination of political decentralization processes and large endowments of natural resources is a factor that renders centralization of natural resource rents politically impossible.

The degree of sharing of the fiscal revenues stemming from natural resources among subnational governments is also increasing over time, due not only to the discovery of the resources, but also to the relative youth of most Latin American constitutions (Ibid.).

Excluding Argentina and Ecuador, in the remaining countries, subnational governments situated in the non-producing areas have direct access to a portion of the rents stemming from natural resources. This is a notable feature of Latin America that has clear merits, once the principle of sharing rents with subnational governments is accepted. In classical federal systems across the world, only the subnational governments situated in the producing areas have direct access to the rents, while the inequalities deriving from the system of allocation are corrected by general equalization systems. In the Latin American countries, general equalization systems do not exist and the inequalities-created by the allocations of rents from natural resources to the producing areas-are, partially, corrected by expanding rent-access to non-producing areas, through 
natural resource or a commodity-specific tax sharing systems. This is the case of Bolivia, Brazil, and Peru.

Consequently, the impact produced by the use of the origin principle for allocation is compensated by the concomitant use of the derivation principle. In Colombia, a specific equalization transfer system, the Sistema General de Regalías, where only royalties contribute to its pool, is used to provide non-producing areas access to revenues.

While natural resource rent sharing expands the revenue sources of subnational governments, it also makes them subject to the volatility of price and production fluctuations, for which they are not particularly well equipped.

When shared only or predominantly with the producing areas, natural resources contribute to increasing horizontal imbalances. This is clearly the case of the Bolivian departments, although the government has recently taken a number of steps to spread the allocation also to non-producing areas, by increasing the rent share going to all municipalities.

The huge interdepartmental inequalities of Bolivia (Brosio et al., 2018) are to be attributed to the unique characteristics of the country, where royalties on natural resources are the only source of revenue for departments. Nonproducing departments are, as a consequence, completely dependent on central government redistribution. Since no general equalization transfer system exists in Bolivia and since the non-producing departments have only access to a share of the rents on oil and gas, the distribution of departmental revenues is highly unequal (Brosio \& Jiménez, 2012).

The case of Bolivia shows the negative impact on regional equality deriving from making subnational government revenues only dependent on natural resource rents. Argentina provides evidence for a different practice. As mentioned before, in Argentina only the producing provinces have direct access to the rents through their royalties. However, provinces have access to their own taxes and to a share of a pool of national taxes. Consequently, while oilproducing provinces have extremely high per capita revenue, no province is left with an unbearably low revenue level (Ibid.).

It is difficult to find research that addresses the question of the impact on regional equality deriving from giving municipalities access to the rents from natural resources. There is no easily manageable information at this local government level. However, there is scanty evidence showing, as expected, that the concentration and randomness of the allocation of royalties is much higher for municipalities. In some cases, royalties can reach astronomically high per capita amounts, increasing regional inequality.

In spite of this heterogeneity, linked to the historical trajectories and social and political processes specific to each country, some general trends can be identified with regard to the regional distribution of these resources. We observe a high asymmetric assignment of tax responsibilities and the distribution of the fiscal revenues from extractive activities to the producer regions (Brosio \& Jiménez, 2015), with a lack of compensation mechanisms to nonproducer regions. 
Some countries in the Andean region share their revenues from nonrenewable natural resources asymmetrically with their local governments. Asymmetrical sharing consists in assigning a fiscal instrument only to the subnational governments of the producing areas, such as the right of levying royalties on oil and gas assigned to the provinces of Argentina. Alternatively, it may consist in assigning a share of the revenue collected by the central government only to the producing areas, as in the case of royalties and income tax in the case of Peru or the hydrocarbon tax (IDH) in Bolivia.

Asymmetrical sharing is a non-necessary consequence of the spatial concentration on natural resources within countries. As a matter of fact, many countries do not use it, preferring to share the revenue with all local governments. Asymmetrical sharing can create huge horizontal imbalances among local governments compromising regional equality, efficiency, and national cohesion.

The fiscal revenues that are more concentrated are those coming from the nonrenewable natural resources sector (Table 2.1). This is a result of the

Table 2.1 Evolution of concentration of regional GDP per capita and subnational revenues: breakdown of revenues by fiscal revenues, tax revenues, and revenues from nonrenewable natural resources. Latin America (selected countries) 2000, 2007 and 2016

\begin{tabular}{|c|c|c|c|c|c|}
\hline \multirow[t]{2}{*}{ Countries } & \multirow[t]{2}{*}{ Year } & \multirow{2}{*}{$\frac{\text { Gap }(\max / \mathrm{min})}{\text { Regional GDP }}$} & \multicolumn{3}{|c|}{ Coefficient of variation } \\
\hline & & & $\begin{array}{l}\text { Fiscal } \\
\text { revenues }\end{array}$ & Tах revenues & $\begin{array}{l}\text { Revenues from } \\
\text { nonrenewable } \\
\text { natural resources }\end{array}$ \\
\hline \multirow[t]{3}{*}{ Argentina } & 2000 & 7.8 & 0.55 & 0.88 & 2.14 \\
\hline & 2007 & 7.6 & 0.63 & 0.78 & 1.97 \\
\hline & 2016 & $\ldots$ & 0.45 & 0.76 & 2.04 \\
\hline \multirow[t]{3}{*}{ Bolivia } & 2000 & 2.7 & 0.88 & 0.76 & $\ldots$ \\
\hline & 2007 & 4.1 & 1.08 & 1.58 & $\ldots$ \\
\hline & 2012 & 4.6 & 1.28 & 1.73 & $\ldots$ \\
\hline \multirow[t]{3}{*}{ Chile } & 2000 & 11.0 & 0.19 & 0.35 & 1.73 \\
\hline & 2007 & 9.2 & 0.25 & 0.39 & 1.70 \\
\hline & 2016 & 6.3 & 0.19 & 0.34 & 1.63 \\
\hline \multirow[t]{3}{*}{ Colombia } & 2000 & 15.7 & 0.79 & 0.85 & 2.72 \\
\hline & 2007 & 7.9 & 0.69 & 0.66 & 2.45 \\
\hline & 2016 & 6.2 & 0.81 & 0.58 & 1.39 \\
\hline \multirow[t]{3}{*}{ Ecuador } & 2000 & 19.1 & 0.67 & 0.90 & 0.73 \\
\hline & 2007 & 20.2 & 0.48 & 0.95 & 0.79 \\
\hline & 2015 & 8.4 & 0.55 & 0.56 & 0.71 \\
\hline \multirow[t]{3}{*}{ Peru } & 2005 & 6.2 & 0.88 & 0.96 & 1.92 \\
\hline & 2009 & 11.1 & 1.14 & 1.00 & 1.84 \\
\hline & 2016 & 4.7 & 0.50 & 0.85 & 1.83 \\
\hline
\end{tabular}

Source: Own elaboration based on official data.

Notes: The figure of the Regional GDP of Argentina for 2007 is taken from the last measurement of the GDP by province which corresponds to 2004 (see Cetrángolo, 2017). 
combination of the asymmetric allocation at the subnational level of tax revenues related to the exploitation of nonrenewable natural resources, coupled with the lack of equalization transfers. The significant concentration of regional GDP is also expressed in the high concentration of fiscal and tax revenues in the countries of the region.

An additional way to show the impact of asymmetric sharing on subnational fiscal inequality is through an indicator derived from the Gini coefficient, in order to capture the relative participation of different sources of revenues in the subnational fiscal inequality (Brosio et al., 2018). Following Lerman and Yitzhaki (1985) and adapting it to the subnational fiscal revenue structure, the Gini coefficient of regional inequality can be decomposed into three independent factors relating to the source of fiscal revenues (in this case it would be nonrenewable natural resources fiscal revenues) relative to the Gini coefficient of subnational fiscal revenues (own fiscal revenues, nonrenewable natural resources fiscal revenues, and other fiscal revenues). Therefore, for the source of revenue from nonrenewable natural resources, the sum of these three components (fourth, sixth, and eighth column) would represent their absolute contribution to total inequality.

Table 2.2 Relative participation in the inequality of subnational tax revenues

\begin{tabular}{|c|c|c|c|c|c|c|c|}
\hline \multirow[t]{2}{*}{ Country } & \multirow[t]{2}{*}{$\begin{array}{l}\text { Fiscal } \\
\text { instrument }\end{array}$} & \multicolumn{2}{|c|}{ Own revenues } & \multicolumn{2}{|c|}{$\begin{array}{l}\text { Revenues from } \\
\text { nonrenewable natural } \\
\text { resources fiscal }\end{array}$} & \multicolumn{2}{|c|}{$\begin{array}{l}\text { Other (transfers, } \\
\text { donations, etc.) }\end{array}$} \\
\hline & & $\begin{array}{l}\text { As } \star \\
\text { of total } \\
\text { revenues }\end{array}$ & $\begin{array}{l}\text { Relative } \\
\text { participation } \\
\text { in inequality } \\
\text { (GINI) }\end{array}$ & $\begin{array}{l}\text { As } \star \\
\text { of total } \\
\text { revenues }\end{array}$ & $\begin{array}{l}\text { Relative } \\
\text { participation } \\
\text { in inequality } \\
\text { (GINI) }\end{array}$ & $\begin{array}{l}\text { As * } \\
\text { of total } \\
\text { revenues }\end{array}$ & $\begin{array}{l}\text { Relative } \\
\text { participation } \\
\text { in inequality } \\
\text { (GINI) }\end{array}$ \\
\hline Argentina & Royalty & 34.6 & 24.7 & S.7 & 17.5 & 58 & 57.8 \\
\hline Bolivia & $\begin{array}{l}\text { Royalty } \\
\text { and tax on } \\
\text { hydrocarbons }\end{array}$ & 9.3 & 8.2 & 43.9 & 40.8 & 46.8 & 51 \\
\hline Colombia & Royalty & 28.1 & 13 & 24.7 & SI.7 & 47.2 & 35.3 \\
\hline Ecuador & Oil revenues & 9.9 & 6.1 & 14.7 & 11.9 & 75.4 & 81.9 \\
\hline Mexico & $\begin{array}{l}\text { Inter- } \\
\text { governmental } \\
\text { transfers } \\
\text { (participations) }\end{array}$ & 14.1 & 40.2 & 33.1 & 30.4 & 52.8 & 50.6 \\
\hline Peru & $\begin{array}{l}\text { Canon, } \\
\text { sobrecanon, } \\
\text { and royalties }\end{array}$ & 6.2 & -2.3 & 14.7 & 30 & 79.2 & 72.3 \\
\hline
\end{tabular}

Source: Own elaboration based on official data.

Coverage for Argentina is the provinces (2015); for Bolivia, autonomous governments, departments, and municipalities; in Colombia, departments and municipalities (2014); in Mexico were considered the federal entities, municipalities, and the city of México (2015); in Peru, local governments (2015). 
Asymmetric allocation consolidates, and in some cases amplifies, territorial disparities. In Table 2.1 and 2.2, a high relative participation of fiscal revenues from nonrenewable natural resources on subnational fiscal inequality can be observed.

Bolivia, Colombia, and Peru represent quite telling examples of the impact of nonrenewable natural resources on subnational finances. In these countries, the participation of this revenue exceeds the 30\% of the Gini composition. The case of Argentina should be highlighted, where the natural resource royalties are constitutionally assigned exclusively to the producing provinces. At an aggregate level, their weight within the total revenues is low, but their participation in the inequality of tax revenues between provinces is considerable (17\%).

The high impact on the inequality that may be related to allocation of these resources between levels of government makes it relevant to consider the design of equalization transfers as an alternative to improve interjurisdictional equity (Searle, 2007), particularly in Latin America and the Andean region. ${ }^{4}$

In addition, the high fluctuations in the prices of these products have resulted in highly volatile fiscal revenues and intergovernmental transfers from the exploitation of nonrenewable natural resources. For example, with regard to the volatility of the resources of the mining canon in Peru, the year-to-year variations of the transferred resources have changed from a maximum of $167 \%$ to a minimum of 20\% (Brosio \& Jiménez, 2015). These fiscal revenue variations make it very difficult for the governments (whether local, regional, or even central) to maintain an adequate and sustainable level of public spending, without a high loss of efficiency and equity in the provision of services and benefits.

\section{Conclusion and challenges}

Beyond the efforts of productive diversification, most of the countries of the Andean region are characterized by their high specialization in products from the extractive sector. This characteristic, coupled with the high volatility of the prices of these products, which today is expressed in the post-boom but a decade ago was expressed in the supercycle, meant strong fluctuations in tax revenues, whether at the level of central or subnational governments.

In the previous decade, the Andean countries experienced a particular stage in their economic history, driven in part by the upswing in commodity prices. This fact manifested in sustained processes of high economic growth and great improvements in social indicators, such as poverty and income inequality. These improvements were achieved in part by the adequate measures taken by policy makers throughout the region, who sought to take advantage of the promising external context of high commodity prices. Among the sample countries, an important fact behind these improvements was a stronger fiscal position attained through various tax reforms.

In this sense, it can be seen how these countries implemented a wide array of reforms taking different approaches that granted a high degree of heterogeneity among them. This is how an amplification of the state ownership took 
place, either through nationalizations in the hydrocarbon sector like in the case of Venezuela or Bolivia, or through renegotiation of contracts in Ecuador also through the strengthening of existing instruments or the introduction of new ones, such as royalty income tax and specific taxes in Bolivia, Ecuador, Colombia, Peru, and Chile, an aspect of great relative importance in the mining sector, where historically the state participation has been reduced; and through the implementation of taxes, duties, participations, or contributions linked to prices or extraordinary profits in several countries, given the high volatility of international prices of nonrenewable resources.

In the post-boom, a context of declining oil and mineral prices poses major challenges to the Latin American economies that are producers/exporters of these products. A heterogeneous impact can be expected. In some countries, the effects will be more pronounced, due to specific characteristics such as the share of the nonrenewable resources in their export structure or the fiscal instruments applied to them. Anyway, at a general level the bonanza cycle led to a partial reversion of the process of diversification that allowed it to increase manufacturing exports. As a result, the share of primary goods and nonrenewable resources and other intensive products in the export structure of the countries concerned increased again (Hanni et al., 2018).

To address the challenges that the actual international scenario poses over the countries analyzed in this chapter, it is not enough just to consider the fiscal impacts on the aggregate, as is usually done in the literature on the subject. Policy makers should also embrace the different mixes of fiscal impacts, which had been and will be heterogeneous among all of the countries analyzed. Lower prices of commodities would mean that these countries should make the necessary efforts to keep their spending budgets in direct relation to potential decreases in fiscal revenues by seeking to diversify sources of revenue, avoiding excessive dependence on exports of nonrenewable resources, through the strengthening of other less volatile tax bases such as property taxes or personal income tax, and implementing countercyclical fiscal mechanisms such as stabilization and saving funds. Other bases such as VAT are more extended throughout the analyzed countries, and direct taxes show a greater margin and are more progressive in distributional terms. Although the impact will be different among the countries, it is crucial that they keep their instruments and tax regimes under analysis and gradually improve them to maximize value and minimize the state's balance of tax collections from extractive sectors.

The post-bonanza has meant, at the level of the central governments, not only a fall in the fiscal relevance of these revenues, but also a reconsideration of the objectives to follow and the tools to use, so as to prioritize not only the fiscal result but also the sustainability in the investments and production of the sector. In the boom period, governments sought to increase fiscal revenues from the sector and their share in the economic rents generated; as prices plummeted, these efforts were moderated or even receded as governments sought to protect production and investment. 
This is a difficult process and must be done with care since there are multiple trade-offs between the different evaluation criteria of fiscal instruments, requiring some balance between the different objectives. This means, for example, maintaining reasonable investment dynamism and achieving, at the same time, a progressive state participation in economic rents derived from natural resource extraction; achieving an adequate sharing of risks among the government and the investors by the means of tax arrangements that can transfer part of the commercial risk that entrepreneurs face to the government; and assuring compliance with a reasonably low administrative cost.

At the central government level, one of the main challenges for countries producing nonrenewable natural resources is to balance the need to close fiscal gaps and to ensure fair participation in the economic income generated by the extractive activity. As emphasized in the chapter, each one of the fiscal instruments analyzed has advantages and disadvantages in light of the objectives pursued by governments. It is essential to find a balance between the need to obtain tax revenues with the rest of the typical tax objectives (efficiency, progressiveness, equity, stability, flexibility) in order to guarantee a flow of public revenues while ensuring the sustainability of investment and production in the sector.

On the intergovernmental allocation and distribution side, the challenges are related to how to avoid the high concentration and significant volatility of these resources. Resulting asymmetries point out to the need to revise those tax assignments from the exploitation of nonrenewable natural resources. In the event that these assignments promote a high concentration of income, the design of equalization transfers that make it possible to compensate for the different resulting capacities can be of great help. The post-boom situation, with prices still below those recorded during the bonanza, can be a good opportunity, in terms of political economy, to move forward with less resistance from the authorities of producing jurisdictions in reforms in the allocation systems and distribution of these resources.

\section{Notes}

1 I appreciate the support and collaboration of Maria Gil Mendoza and Ignacio Ruelas; and the comments of Giorgio Brosio, Barbara Fritz, Bettina Schorr, Gerardo Damonte, Andrea Podestá, and Hans-Jürgen Puhle.

2 For more details about the implementation of fiscal reforms in that period, see Hanni, Jiménez and Ruelas (2018)

3 In some of these cases, for example in Peru, since the amending of Mining Royalties Law in 2011, not only the levels of taxation have been altered but scales of varying rates were established according to easily verifiable criteria, like the level of production, location and depth of the wells, the type of resource extracted, or other variables related to the cost structure (see Hanni, Jiménez \& Ruelas, 2018).

4 Brosio and Jiménez (2015) and Brosio, Jiménez \& Ruelas (2018), taking as reference the theoretical principles of interjurisdictional fiscal equity, review the high impact of the exploitation of natural resources on the territorial distribution of fiscal revenues and the effect of the implementation of equalization transfer systems, including fiscal revenues from natural 
resources, at the level of the intermediate governments of Argentina and Peru. In both cases, territorial fiscal revenue inequality falls significantly if these revenues are distributed with equalization mechanisms.

\section{References}

Acquatella, J., Altomonte, H., Arroyo, A., \& Lardé, J. (2013). Rentas de recursos naturales no renovables en América Latina y el Caribe: Evolución 1990-2010 [Serie Seminarios y Conferencias $\left.N^{\circ} 72\right]$. Naciones Unidas. ISSN 1680-9033.

Brosio, G., \& Jiménez, J. P. (2012). The intergovernmental allocation of revenue from natural resources: Finding a balance between centripetal and centrifugal pressure. In G. Brosio \& J. P. Jiménez (Eds.), Decentralization and reform in Latin America (pp. 290-320). Edward Elgar Publishing. https://doi.org/10.4337/9781781006269.00016

Brosio, G., \& Jiménez, J. P. (2015). Equalization grants and asymmetric sharing of natural resources: Options for Latin America. Urban Public Economics Review, 21, 12-63. www. redalyc.org/articulo.oa?id $=50443064001$

Brosio, G., Jiménez, J. P., \& Ruelas, I. (2018). Territorial inequality, equalization transfers and asymmetric sharing of nonrenewable natural resources in Latin America. CEPAL Review, 126, 63-85. hdl.handle.net/11362/44558

Cetrángolo, O. (2017, July 20). ¿Qué sabemos sobre las estructuras productivas regionales? Nuevos Papeles (NP). www.nuevospapeles.com/nota/4549-iquest-que-sabemos-sobre-lasestructuras-productivas-regionales

Comisión Económica para América Latina y el Caribe-CEPAL. (2013). Panorama fiscal de América Latina y el Caribe 2013: Reformas tributarias y renovación del pacto fiscal. Naciones Unidas.

Comisión Económica para América Latina y el Caribe-CEPAL. (2017). Panorama fiscal de América Latina y el Caribe: La movilización de recursos para el financiamiento del desarrollo sostenible. Naciones Unidas. ISBN: 978-92-1-058580-4

Gómez Sabaíni, J. C., Kacef, O., \& Morán, D. (2018). International insertion, volatility and fiscal resources in countries specialized in extractive industries: Between a rock and a hard place? In J. Atria, C. Groll, \& M. F. Valdés (Eds.), Rethinking taxation in Latin America (pp. 123-158). Palgrave Macmillan.

Hanni, M., Jiménez, J. P., \& Ruelas, I. (2018). Ciclo de precios y regímenes fiscales vinculados con los recursos naturales no renovables en América Latina y el Caribe. CEPAL, Serie Macroeconomía del Desarrollo, 195. http://hdl.handle.net/11362/44239

Lerman, R., \& Yitzhaki, S. (1985). Income inequality effects by income source: A new approach and applications to the United States. MIT Press, The Review of Economics and Statistics, 67(1), 151-156. https://doi.org/10.2307/1928447

Muñoz, A. F., Radics, G. A., \& Bone, C. (2016). Subnational fiscal disparities and intergovernmental transfers in LAC. Review of Public Economics, 219(4), 35-66. https://doi. org/10.7866/HPE-RPE.16.4.2

Searle, B. (2007). Revenue sharing, natural resources and fiscal equalization. In J. MartínezVázquez \& B. Searle (Eds.), Fiscal equalization: Challenges in the design of intergovernmental transfers (pp. 371-401). Springer. https://doi.org/10.1007/978-0-387-48988-9 